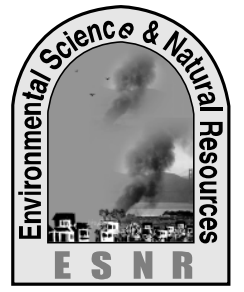

J. Environ. Sci. \& Natural Resources, 5(2): 67-72, 2012

ISSN 1999-7361

\title{
Pickle and Chutney Development from Fresh Hog Plum (Spondias dulcis)
}

\author{
M. H. R. Bhuiyan
}

Department of Food Engineering and Technology, State University of Bangladesh, Dhaka

\begin{abstract}
The experiment was conducted to develop pickle and chutney from fresh hog plum fruit. The pickle was made with 5\%, $10 \%$, $15 \%$ and $20 \%$ salt concentration. The chutneys were made with $25 \%, 30 \%, 35 \%$ and $40 \%$ sugar concentration. Among them, the best pickle and chutney was identified on the basis of overall acceptability. The study showed that the color, flavor, texture and overall acceptability of different pickles and the chutneys were different. The pickle (P15) made with $15 \%$ salt and the chutney (C40) made with $40 \%$ sugar concentration was best among others of the similar product. Higher concentration of sugar and salt gives higher acceptability for chutney and pickle, respectively. Among different changes in chemical composition, moisture and vitamin C concentration were prominent during preparation of pickle and chutney. The moisture content was $59.69 \%$ and $43.08 \%$ for pickle and chutney respectively which were nearly two third to half of the initial concentration of fresh hog plum fruit. The storage stability was studied for both the products and it is seen that chutney (4 month) was lower than storage stability of pickle (5 month).
\end{abstract}

Key Word: Chutney, Hog plum, Pickle, Overall acceptability

\section{Introduction}

Importance of fruit in human diet is well recognized. Many people suffering with malnutrition due to inadequate and imbalance diet. The daily per capita fruit requirement is about $250-300 \mathrm{gm}$ but the availability may not be enough due to various reasons. Among different fruits one of the less expensive is Hog-plum (Spondias dulcis). Hog-plum (Amra) is an underutilized fruit in Bangladesh. It belongs to the family of Anacardiaceae and its scientific name is Spondias dulcis. It is used as food and medicine since time immemorial. Hog-plum is a fruit of mixed taste of sweet and sour which is familiar in botany as Droop, has gained much importance in modern medicine for their pharmacological values. It is very useful for the treatment against bacillary dysentery, tuberculosis infection as it acts as blood purifier. Moreover, it is also effective against scurvy, rickets and some other complex diseases. It helps to reduce serum cholesterol, high blood pressure and has antitumor property. Hog-plum is valuable health food, which are low in calories, high in vegetable proteins, zinc, chitin, fiber, vitamins and minerals. It contains very good amount of Vitamin C. In addition to physical changes, the shelf-life of fresh hog-plums is also restricted by bacterial spoilage and enzymatic browning. The use of hog-plum is still unorganized and primitive. Due to poor keeping quality and difficulties of transportation, preservation and marketing facilities, a huge quantity of these valuable fruits are being damaged, spoiled and wasted specially during the peak season. To reduce the wastage and to get a reasonable price by the producer of this fruit, preservation is necessary. It is possible to increase the utility of this fruit. Hog-plums are usually eaten raw and can be used for preparation of pickles, chutney and processed food (Akther, 2006). It is apparent that research work need to be undertaken for processing and preservation of hogplum by using locally available machineries and thus low level technology involving minimal capital investment. For long term preservation, processing is considered to be the best method. Therefore pickling and chutney may be the realistic and most convenient methods for processing hog-plum. When any food (fruits, vegetables, fish or meat) is preserved by natural salt or vinegar or oil, then the processed food is called pickles. Pickles are widely acceptable and usable food in Bangladesh and India. The pickles make the dish or food taste better. The pickle generally acts as an appetizer. The assimilation of gastric is better thereby improving the digestion. Pickles are an edible product that has been preserved and flavored in a solution of brine and edible acid such as vinegar. Salt, vinegar and spices are commonly used in complementary action in pickling. Spices vary in their antibacterial activity, some (mustard oil) being very active and others (black perper) having little activity (Desrosier, 1977). The chutney is the typical Indian relish, whether it's sweet, sour or tangy in taste. Chutney is made with a mixture of fruits, herbs and spices. They are usually prepared with fresh ingredients, which mean they need to eaten straight away or stored in a refrigerator. Pickles on the other hand, contain a combination of salt and a riot of spices, which preserve seasonal fruits and vegetables in a piquant sauce (Kapoor, 
2001). The present study was undertaken with the following objectives (1) to find out optimal formulation of hog-plum pickle and chutney, and (2) to study the storage-life of the developed hog-plum pickle and chutney.

\section{Materials and Methods}

The experiment was conducted in the laboratory of the Department of Food Engineering and Technology, State University of Bangladesh. Hog-plum (Spondias dulcis) collected from local market. The other materials such as salt, sugar, sodium benzoate, onion, garlic, ginger, cinnamon, cardamom, cloves, turmeric powder, cumin powder, red chili powder, and packaging materials were collected from the laboratory stock.

\section{Formulation of pickles and chutney}

There were four different formulations of pickles and chutney each. Salt was more prominent ingredient among the formulations of pickles and for chutney, sugar was prominent as described by Srivastava \& Kumar (2003). The use of vinegar and mustard oil was more in pickle formulations as described by (Etchells et al., 1973) than chutney. The amount of ginger paste and garlic paste was $50 \mathrm{~g}$ each for all the formulations of pickles and chutney. $10 \mathrm{~g}$ red chili powder and $5 \mathrm{~g}$ cumin powder was common for all the formulations of pickles and chutney and the Nabenzoate at specified rate $(0.7 \mathrm{~g} / \mathrm{Kg}$ finished product $)$ was used to all formulation. For each $\mathrm{kg}$ Hog plum slice/paste to prepare the different formulations of pickles and chutney were as follows.

Table1. Different Formulation of Pickle and chutney

\begin{tabular}{|c|c|c|c|c|c|c|c|c|}
\hline \multirow{2}{*}{ Ingredient } & \multicolumn{9}{|c|}{ Pickles } & \multicolumn{4}{c|}{ Chutney } \\
\cline { 2 - 9 } & P05 & P10 & P15 & P20 & C25 & C30 & C35 & C40 \\
\hline Sugar & $50 \mathrm{~g}$ & $50 \mathrm{~g}$ & $50 \mathrm{~g}$ & $50 \mathrm{~g}$ & $25 \%$ & $30 \%$ & $35 \%$ & $40 \%$ \\
\hline Salt & $5 \%$ & $10 \%$ & $15 \%$ & $20 \%$ & $15 \mathrm{~g}$ & $15 \mathrm{~g}$ & $15 \mathrm{~g}$ & $15 \mathrm{~g}$ \\
\hline Mustard oil & $250 \mathrm{ml}$ & $250 \mathrm{ml}$ & $250 \mathrm{ml}$ & $250 \mathrm{ml}$ & $150 \mathrm{ml}$ & $150 \mathrm{ml}$ & $150 \mathrm{ml}$ & $150 \mathrm{ml}$ \\
\hline Vinegar & $150 \mathrm{ml}$ & $150 \mathrm{ml}$ & $150 \mathrm{ml}$ & $150 \mathrm{ml}$ & $50 \mathrm{ml}$ & $50 \mathrm{ml}$ & $50 \mathrm{ml}$ & $50 \mathrm{ml}$ \\
\hline Postadana & $10 \mathrm{~g}$ & $10 \mathrm{~g}$ & $10 \mathrm{~g}$ & $10 \mathrm{~g}$ & $5 \mathrm{~g}$ & $5 \mathrm{~g}$ & $5 \mathrm{~g}$ & $5 \mathrm{~g}$ \\
\hline Mace \& Nutmeg & $10 \mathrm{~g}$ & $10 \mathrm{~g}$ & $10 \mathrm{~g}$ & $10 \mathrm{~g}$ & $5 \mathrm{~g}$ & $5 \mathrm{~g}$ & $5 \mathrm{~g}$ & $5 \mathrm{~g}$ \\
\hline Turmeric powder & $5 \mathrm{~g}$ & $5 \mathrm{~g}$ & $5 \mathrm{~g}$ & $5 \mathrm{~g}$ & \multicolumn{5}{|c|}{ Not used } \\
\hline pach forun & $5 \mathrm{~g}$ & $5 \mathrm{~g}$ & $5 \mathrm{~g}$ & $5 \mathrm{~g}$ & \multicolumn{5}{|c}{} \\
\hline
\end{tabular}

\section{Preparation of Pickle}

Fresh hog plum were peeled by knife and kept in a pot with water to retard the enzymatic browning. Then the peeled hog-plum were cored and sliced and the slices were blanched at $80-85^{\circ} \mathrm{C}$ for $5 \mathrm{~min}$. Mustard oil was taken in a stainless steel vessel. After some heating the spices were added and boiled till the brown color developed. Then hog-plum pieces were added, mixed thoroughly and heated. After that predetermined amount of salt, sugar and vinegar were mixed. Then the vessel removed from the heater and finished product was properly mixed with sodium benzoate at specified rate $(0.7 \mathrm{~g} / \mathrm{Kg}$ finished product) as describe described by (Srivastava \& Kumar, 2003) and finally poured in bottles and sealed.

\section{Preparation of Chutney}

Then slicing and coring operation were performed on the fresh and peeled hog plum. Then heating and crushing were done and the pulp of hog-plum extracted by mechanical means as described by cruses (1958). In a stainless steel vessel mustard oil was heated till reached to brown color and then all the spices were added and thoroughly mixed with the hog plum paste and heated till the required consistency were reached. Then the vessel was removed from the heater and cooled at room temperature. The prepared chutney was filled in bottles with sodium benzoate at specified rate $(0.7 \mathrm{~g} / \mathrm{Kg}$ finished product) as describe described by (Srivastava \& Kumar, 2003) and sealed and finally stored.

\section{Sensory Evaluation}

The consumer acceptability of the developed product was evaluated by a taste-testing panel using 1-9 point Hedonic Rating Test (HRT). The 10 person was selected as panelist for taste testing. Each sample was supplied to the panelist and asked to give score for color, flavor, texture and overall acceptability in a 1-9 point scale. The panelist scores were analyzed with software.

\section{Chemical Analysis}

Total soluble solids (TSS), moisture, $\mathrm{pH}$ and vitamin $\mathrm{C}$ content were determined according to the AOAC (2005). 


\section{Results and Discussion}

\section{Significant parameter of pickle}

The color, flavor, texture and overall acceptability of pickles made with different concentration of salt were evaluated by 10 panel judge. Sample P05 was made with $5 \%$ salt, P10 was made with $10 \%$, P15 was made with $15 \%$ and Sample P20 was made with $20 \%$ salt. The analysis of variance (ANOVA) was performed for color, flavor, texture and overall acceptability of sample P05, P10, P15 and P20.

Table2. ANOVA (Analysis of variance) for color, flavor, texture and overall acceptability of Pickle

\begin{tabular}{|c|c|c|c|c|c|c|c|}
\hline \multirow{2}{*}{$\begin{array}{l}\text { Sensorial } \\
\text { Property }\end{array}$} & \multicolumn{3}{|c|}{ Statistical Parameter } & \multirow{2}{*}{$\begin{array}{l}\text { Sensorial } \\
\text { Property }\end{array}$} & \multicolumn{3}{|c|}{ Statistical Parameter } \\
\hline & $\begin{array}{c}\text { Sources of } \\
\text { variance }\end{array}$ & $\begin{array}{l}\text { Mean } \\
\text { Square }\end{array}$ & Probability & & $\begin{array}{c}\text { Sources of } \\
\text { variance }\end{array}$ & $\begin{array}{l}\text { Mean } \\
\text { squares }\end{array}$ & Probability \\
\hline \multirow{3}{*}{ Color } & Products & 6.692 & 0.0000 & \multirow{3}{*}{ Texture } & Products & 6.092 & 0.0000 \\
\hline & Judge & 0.358 & 0.6970 & & Judge & 0.403 & 0.2149 \\
\hline & Error & 0.506 & & & Error & 0.277 & \\
\hline \multirow{3}{*}{ Flavor } & Products & 6.933 & 0.0000 & \multirow{3}{*}{$\begin{array}{l}\text { Overall } \\
\text { Acceptability }\end{array}$} & Products & 5.933 & 0.0000 \\
\hline & Judge & 0.100 & 0.9647 & & Judge & 0.433 & 0.1266 \\
\hline & Error & 0.322 & & & Error & 0.248 & \\
\hline
\end{tabular}

Note: degree of freedom (df) were 3, 9 and 27 for products, judge and error respectively

There was statistical significant difference in color among the samples as the $\mathrm{P}$ value was $0.0000<0.05$ (Table 2). And the $\mathrm{P}$ value for flavor, texture and overall acceptability also indicates that the samples were significantly different in flavor, texture and Overall acceptability (Table 2). These differences may be due to variation in their formulation especially for salt concentration as the other ingredients was same for each formulation.

\section{Significant parameter of chutney}

The color, flavor, texture and overall acceptability of chutney made with different concentration of sugar were evaluated by 10 panel judge. Sample C25 was made with $25 \%$ sugar, C30 was made with $30 \%$, C35 was made with $35 \%$ and $\mathrm{C} 40$ was made with $40 \%$ sugar. The analysis of variance (ANOVA) was performed for color, flavor, texture and overall acceptability of sample C25, C30, C35 and C40.

Table3. ANOVA (Analysis of variance) for color, flavor, texture and overall acceptability of Chutney

\begin{tabular}{|c|c|c|c|c|c|c|c|}
\hline \multirow{2}{*}{$\begin{array}{l}\text { Sensorial } \\
\text { Property }\end{array}$} & \multicolumn{3}{|c|}{ Statistical Parameter } & \multirow{2}{*}{$\begin{array}{l}\text { Sensorial } \\
\text { Property }\end{array}$} & \multicolumn{3}{|c|}{ Statistical Parameter } \\
\hline & $\begin{array}{l}\text { Sources of } \\
\text { variance }\end{array}$ & $\begin{array}{c}\text { Mean } \\
\text { squares }\end{array}$ & Probability & & $\begin{array}{c}\text { Sources of } \\
\text { variance }\end{array}$ & $\begin{array}{c}\text { Mean } \\
\text { squares }\end{array}$ & Probability \\
\hline \multirow{3}{*}{ Color } & Products & 10.200 & 0.0000 & \multirow{3}{*}{ Texture } & Products & 3.492 & 0.0004 \\
\hline & Judge & 0.156 & 0.7398 & & Judge & 0.225 & 0.8332 \\
\hline & Error & 0.237 & & & Error & 0.418 & \\
\hline \multirow{3}{*}{ Flavor } & Products & 5.367 & 0.0000 & \multirow{3}{*}{$\begin{array}{l}\text { Overall } \\
\text { Acceptability }\end{array}$} & Products & 7.492 & 0.0000 \\
\hline & Judge & 0.111 & 0.9455 & & Judge & 0.692 & 0.111 \\
\hline & Error & 0.311 & & & Error & 0.381 & \\
\hline
\end{tabular}

Note: degree of freedom (df) were 3, 9 and 27 for products, judge and error respectively.

There was statistical significant difference in color, flavor and overall acceptability among the samples as the $\mathrm{P}$ value was $0.0000<0.05$. And the $\mathrm{P}$ value for texture was $0.0004<0.05$ indicates that the samples were different in texture (Table.3). The samples C25, C30, C35 and C40 were significantly different in color, flavor, texture and Overall acceptability. These differences may be due to variation in their preparation, especially for sugar concentration as the other ingredients was same for each formulation.

\section{Salt concentration effect on pickle}

From table 4, among different samples (pickle) the highest score (6.8) for color was for sample P15 followed by P20 and lowest score (4.8) for P05 preceded by P10. For flavor the highest score (6.7) was for sample P15 followed by P20 and lowest score (4.7) for P05 preceded by P10. For texture the highest score (6.7) for P15 and followed by P20 and there is lowest score (5.0) for P10 preceded by P05. Finally for overall acceptability, the highest score (6.7) was 
for sample P15 followed by P20 and lowest score (5) for P05 and was preceded by P10. For color and flavor there is no statistical significant difference between sample P20 and P10 as they were suffixed by same letter (b). There is significance difference between them for texture and overall acceptability as P20 suffixed by letter "b" whereas P10was suffixed by letter "c". Sample P15 was significantly different from all other pickle samples as suffixed by letter (a) and ranked as "Like slightly" due to its mean score (6.7) which is very near to 7 and may be ranked as
"Like Moderately" as per Rangana (1991) for each of sensory parameter. Sample P15 was identified as best sample (pickle) as its score for color, flavor, texture and most importantly overall acceptability was highest among the others. Sample P15 contains more salt than P05 and P10 but less than P20. So it can be claimed that high but not excessive amount of salt gives better quality pickle where other ingredients remain same as the P15 was made with $15 \%$ salt and P20 was made with $20 \%$ salt (Table $1 \& 4$ )

Table4. Mean score of color, flavor, texture and overall acceptability of Preserve and Chutney

\begin{tabular}{|c|c|c|c|c|c|}
\hline \multirow{3}{*}{ Product } & \multirow{3}{*}{ Sample } & \multicolumn{4}{|c|}{ Sensory attributes } \\
\cline { 2 - 6 } & $\mathrm{P} 05$ & color & flavor & texture & overall acceptability \\
\hline \multirow{4}{*}{ Pickle } & $\mathrm{P} 10$ & $4.8^{\mathrm{c}}$ & $4.7 \mathrm{c}$ & $5.1 \mathrm{c}$ & $5.0^{\mathrm{c}}$ \\
\cline { 2 - 6 } & & $5.7^{\mathrm{b}}$ & $5.5 \mathrm{~b}$ & $5.0 \mathrm{c}$ & $5.2^{\mathrm{c}}$ \\
\cline { 2 - 6 } & $\mathrm{P} 15$ & $6.8^{\mathrm{a}}$ & $6.7^{\mathrm{a}}$ & $6.7^{\mathrm{a}}$ & $6.7^{\mathrm{a}}$ \\
\cline { 2 - 6 } & & $5.8^{\mathrm{b}}$ & $5.9^{\mathrm{b}}$ & $5.7^{\mathrm{b}}$ & $5.9^{\mathrm{b}}$ \\
\cline { 2 - 6 } & $\mathrm{P} 20$ & 0.6527 & 0.5207 & 0.4829 & 0.4570 \\
\hline \multirow{4}{*}{ Chutney } & LSD value & $5.1^{\mathrm{d}}$ & $5.5^{\mathrm{c}}$ & $6.0^{\mathrm{b}}$ & $6.0^{\mathrm{d}}$ \\
\cline { 2 - 6 } & $\mathrm{C} 25$ & $5.7^{\mathrm{c}}$ & $5.9^{\mathrm{bc}}$ & $6.4^{\mathrm{b}}$ & $6.6^{\mathrm{c}}$ \\
\cline { 2 - 6 } & $\mathrm{C} 30$ & $6.6^{\mathrm{b}}$ & $6.4^{\mathrm{b}}$ & $6.5^{\mathrm{b}}$ & $7.3^{\mathrm{b}}$ \\
\cline { 2 - 6 } & $\mathrm{C} 35$ & $7.4^{\mathrm{a}}$ & $7.2^{\mathrm{a}}$ & $7.4^{\mathrm{a}}$ & 0.5664 \\
\cline { 2 - 6 } & C40 & 0.4467 & 0.5117 & 0.5933 & \\
\hline
\end{tabular}

\section{Sugar concentration effect on chutney}

From Table 4, among different sample (chutney) the highest score (7.4) for color was for sample C40 followed by $\mathrm{C} 35$ and lowest score (5.1) for $\mathrm{C} 25$ preceded by $\mathrm{C} 30$. The highest score (7.2) for flavor, (7.4) for texture and (8.0) for Overall acceptability was for sample C40 and the order was similar as noted earlier for color. For flavor and texture there was no statistical significant difference between sample C35 and C30 as they were suffixed by same letter (b). Sample C40 was significantly different from all other as suffixed by different letter (a). On the basis of overall acceptability, the sample C40 was ranked as "Like very much" due to its mean score
(8.0) as per Rangana (1991). Sample C40 was identified as best sample (candy) as its score for color, flavor, texture and most importantly overall acceptability was highest among the others. So it can be claimed that the high concentration of sugar gives better quality chutney as the C40 was made with $40 \%$ sugar whereas C35, C30 and C25 was made with low concentration (less than 40\%) of sugar. Comparing all the sample of pickles and chutneys, it was clear that highest acceptability (8.8) was for C40. From this it can be claimed that higher sugar concentration gives higher acceptability (Table. $4 \& 1$ ) as the taste is prominently influenced by sweetness (Bhuiyan et al., 2012).

\section{Laboratory attributes}

Table.5 Compositional analysis of fresh hog plum, pickle and chutney

\begin{tabular}{|c|c|c|c|c|c|}
\hline Sample & Moisture (\%) & Ash (\%) & pH & Vitamin C (mg/ 100 g) & TSS (\%) \\
\hline Fresh Hog plum & 86.69 & 0.78 & 2.7 & 30.9 & 6.5 \\
\hline Pickle & 59.69 & 1.42 & 3.12 & 4.70 & 35.5 \\
\hline Chutney & 43.08 & 1.40 & 3.72 & 4.55 & 55.5 \\
\hline
\end{tabular}

Initially the moisture content of fresh hog plum was $86.69 \%$, ash $0.78 \%, 30.9 \mathrm{mg} / 100 \mathrm{~g}$ vitamin $\mathrm{C}$ and $\mathrm{pH}$
2.70. All the parameter i.e moisture, ash, acidity and vitamin of both the pickle and chutney were more or 
less different than the fresh hog plum. But among different parameter water content and vitamin C concentration was most prominently different than the fresh fruit. The moisture content of pickle was $59.69 \%$ and $43.08 \%$ for chutney. It was clear that the moisture content was reduced to near about half of the initial $(86.69 \%)$ concentration for chutney and the reduction is about two third for pickle (Table 5). This finding was similar to Ponting et al. (1966) as described that $50 \%$ of the water of fruit pieces could be removed by mixing with dry sucrose or by immersion in concentrated solution. The TSS was $35.50 \%$ and $55.50 \%$ for pickle and chutney respectively. It was observed that TSS increased and vitamin $\mathrm{C}$ concentration decreased as storage time increased. The observation was similar for vitamin C concentration as described by Saron et al. (2007). TSS percentage increased due to loss in moisture content and this is in agreement with Barwal et al. (2005). The ash content was changed nearly twice of the initial concentration may be due to reduction in moisture of the initial volume. The $\mathrm{pH}$ of the pickle and chutney was more than the initial $\mathrm{pH}$ of hog plum. The vitamin $\mathrm{C}$ concentration was near about $5 \mathrm{mg} / 100 \mathrm{~g}$ sample for both the pickle and chutney which were different from initial concentration (30.9 $\mathrm{mg} / 100 \mathrm{~g}$ ). This difference may be due to processing method applied. Factors responsible for vitamin C losses are: temperature, oxidation, acidity, $\mathrm{pH}$ and metal trace (Villota and Hawkes, 1992).The vitamin$\mathrm{C}$ content of develop products were low due to the fact that vitamin-C is readily oxidized. Moreover reduction of vitamin-C follows the first order kinetic reaction and the rate constant has and Arrhenius type relationship with absolute temperature (Heldman, 1974; Augustin et al. 1979 and Islam, 1980).

\section{Storage stability}

Observation of color, flavor, turbidity and texture of the developed products has been shown in Table.6. The color, flavor and texture of pickle were acceptable as there were no changes up to 5 months of storage. The remarkable change was noticed at 6 months of preservation and the pickle remarked as unacceptable to consume. The color, flavor and turbidity of chutney were acceptable as there were no changes up to 4 months of storage. The remarkable change was noticed at 5months of preservation and the chutney remarked as unacceptable to consume. The changes occurred possibly due to fermentation in presence of fungus (mold and yeast) as Fraziar and Westheff (1978) describe that main spoilage organism for fruit products are mold and yeast (Table. 6). Comparing pickle and chutney it was clear that the storage stability of pickle is higher than chutney and their storage life was in the range described by (Gupta et al., 1992).

Table.6 Effect of storage on the quality of pickle and chutney

\begin{tabular}{|c|c|c|c|c|c|c|c|c|}
\hline \multirow{2}{*}{$\begin{array}{c}\text { Storag } \\
\text { e } \\
\text { period } \\
\text { (month } \\
\text { ) }\end{array}$} & \multicolumn{4}{|c|}{ Pickle } & \multicolumn{4}{|c|}{ Chutney } \\
\hline & Color & Flavor & Texture & Remarks & Color & Flavor & Turbidity & Remarks \\
\hline 1 & Brown & Satisfactory & Firm & \multirow{5}{*}{ Acceptable } & Brown & Satisfactory & Opaque & \multirow{4}{*}{ Acceptable } \\
\hline 2 & Brown & Satisfactory & Firm & & Brown & Satisfactory & Opaque & \\
\hline 3 & Brown & Satisfactory & Firm & & Brown & Satisfactory & Opaque & \\
\hline 4 & Brown & Satisfactory & Firm & & Brown & Satisfactory & Opaque & \\
\hline 5 & Brown & Satisfactory & Firm & & $\begin{array}{l}\text { Light } \\
\text { Brown }\end{array}$ & Off flavor & Opaque & \multirow{2}{*}{$\begin{array}{c}\text { Not } \\
\text { acceptable, } \\
\text { may } \\
\text { fermentation } \\
\text { occurred due } \\
\text { to more } \\
\text { sugar }\end{array}$} \\
\hline 6 & $\begin{array}{l}\text { Light } \\
\text { Brown }\end{array}$ & Off flavor & Firm & $\begin{array}{c}\text { Not } \\
\text { acceptable }\end{array}$ & $\begin{array}{l}\text { Light } \\
\text { Brown }\end{array}$ & Off flavor & Opaque & \\
\hline
\end{tabular}




\section{Conclusion}

The best pickle and chutney of the hog plum was identified based on the overall acceptability. Sugar and salt concentration showed most prominent effect on chutney and pickle respectively. Acceptability, Color, flavor and texture were influenced by sugar for chutney and by salt for pickle. Both the pickle and chutney contains reduced amount of moisture and vitamin $\mathrm{C}$ than the fresh fruit. The storage stability of pickle was 5 month and is higher than storage stability 4 month for chutney.

\section{References}

Akther, S. 2006. Kinetics of Dehydration of Hogplum (Spondias dulcis) and Development of Jelly and Leather (Thesis). Department of Food Technology and Rural Industries, Bangladesh Agricultural University, Mymensingh

AOAC Methods. 2005. Official Method of Analysis $12^{\text {th }}$ edition. Association of Official Agricultural Chemists, Washington, D.C.USA

Augusti, K. T. 1977. Hypocholestcholacmic effect of garlic (Allium sativum L.). Indian J. Exp. Bio., 15(6): 489-790.

Barwal, V. S.; Sharma, R. and Singh, T.K. (2005). Development and evaluation of dietetic bitter gourd ready-to-serve drink. Journal of Food Science and Technology Mysore., 42(2): 202-205.

Bhuiyan, M. H. R., Shams-Ud-Din, M. and Islam, M. N. 2012. Development of Functional Beverage Based on Taste Preference. Journal of Environmental Science and Natural Resources, 5(1): 83-87.

Cruess, W. V. 1958. Commercial fruits and vegetables. $4^{\text {th }}$ edition. McGraw Hill Book. Inc. USA. pp. 456: 457.

Desrosier, N. W. 1977. The Technology of Food Preservation. The AVI Publishing Co. the Edition. West port. USA. pp. 264.

Etehells, J. J.; Fleming, H. P.; Kelling, R. E. and Thompson, R. L. 1973. A new crop for concentrated yield of pickles. Proceedings of the first national symposium, New crops. USA. pp. 23: 26.

Fraziar, W. C. and Westheff, D. C. 1978. Food Microbiology, ${ }_{3}$ rd Edn. McGrow-Hill Book Co., USA. 2-95.
Gupta, P. K. 1992. Hand book of export oriented food processing products. Consultant and Engg. Pvt. Ltd. Delhi. pp. 43: 45.

Heldman, D. R. 1974. Food process engineering.The AVI pub. Co. reprint edition. Westport, USA. pp. 237-311.

Islam, M. N. 1980. Use of solar energy for development of shelf stable potato products. Ph.D. Thesis. Royal Veterinary and Agricultural University, Copenhagen, Denmark

Kappor, S. 2001. Pickles and chutney in India. Journal of Food Science Technology. Vol. 5: 23.

Ponting, J. D.; Watters, G. C.; Forrey, R. R.; Jackson, R. and Stanley, W. L. 1966. More flavorful dried fruits. In: Food Processing.

Ranganna, S. 1991. Handbook of Analysis and Quality Control for Fruit and Vegetable Products, 2nd Ed. Tata McGraw-Hill Publishing Company Ltd, New Delhi, India.

Saron, E. S.; Dantas, S.T.; Menezes, H. C.de.; Soares, B. M. C. and Nunes, M. F. 2007. Sensorial stability of ready to drink passion fruit juice packaged in tinplate cans. Ciencia $e$ Tecnologia de Alimentos, 27(4): 772-778.

Srivastava, R. P. and Kumar, S. 2003. Fruit and Vegetable Preservation Principles and Practices. $3^{\text {rd }}$ ed. International Book Distributing Co. Lucknow-226004, U. P India. Pp 93-96, 300-302.

Villota and Hawkes. 1992. Kinetics in food System. In:Hand Book of Food Engg.Edt. by Heldman, D.R 1992. P:58-60. 